\title{
ARS Interactive Teaching Mode for Financial Accounting Course based on Smart Classroom
}

\author{
https://doi.org/10.3991/ijet.v14i03.10104 \\ Shenglei Dai \\ Chongqing City Vocational College, Chongqing, China \\ dai881890@163.com
}

\begin{abstract}
Many problems exist in traditional financial accounting course teaching, such as old-fashioned information-based teaching method, singe teaching method, and insufficient student-teacher interaction in the teaching process. These problems influence the effect of course teaching. To enhance student-teacher interaction, improve learning effect, and promote training quality of financial accounting talents, an ARS interactive teaching mode for financial accounting course that integrates Smart Classroom was proposed in this study. Cognitive flexibility theory was used as the theoretical guidance, and Smart Classroom teaching environment was combined to introduce ARS system and multimedia circuit system technology with the PowerPoint (PPT) function of the next page preview. The complete ARS interactive teaching mode based on Smart Classroom was constructed from the following: pre-class, in-class, and after-class integrated teaching; feedback teaching; and Peer Class. Meanwhile, a teaching experiment was conducted in financial accounting course. ARS interactive teaching mode based on Smart Classroom could significantly promote students' autonomous learning, collaborative communication, classroom activity, and innovative thinking. The teaching mode was welcomed and supported by students. The mode plays a great promotion role in driving integration of information technology and education, achieving educational informationization, and improving the teaching effect of a financial accounting major.
\end{abstract}

Keywords-Smart Classroom; feedback teaching, ARS interactive teaching mode; financial accounting course; educational informationization

\section{$1 \quad$ Introduction}

With the rapid development of internet and sensor technologies, the state starts to emphasize the construction of smart environment, such as smart community, smart city, Smart Classroom, and smart campus. Educational informationization has become the mainstream of educational reform. Smart Classroom mainly refers to a new teaching environment, i.e., a new classroom based on relevant computer techniques, such as network technique, media technology, sensor technology, and artificial intelligence technology. The class can perceive context and intelligently manage the teaching environment [1]. Smart Classroom can optimize the presentation of teaching content 
for more convenient acquisition of learning resources. It can facilitate interaction and exchange between teachers and students and among students in class. Audience Response System (ARS) is one of the multimedia technology modules supporting Smart Classroom [2]. ARS helps teachers and students interact. It also assists teachers in mastering students' conditions and in adjusting teaching in real time. Moreover, ARS system can greatly improve students' initiative in the learning process and promote teaching effect of Smart Classroom through interaction. Digital teaching refers to teaching based on computer, camera, and projector [3]. In the whole teaching process, teachers and students are in the digital teaching environment (digital teaching mode + digital teaching resources). Since college educational informationization has been implemented, the application and construction of digital teaching have been perfected. Digital teaching is applied in many college courses. In accordance with the existing studies, digital teaching involves extensive subjects, including specific courses, such as college physics, software engineering, medicine, statistics, and engineering drawing [4]. It also involves public courses, such as ideological and political course, college PE, college English, and computer education. There are professional subjects such as accounting, foreign languages, chemical engineering, electrotechnics, electronics, and civil engineering. The application of digital teaching in higher education courses could significantly facilitate the teaching effect [5].

With improvement in social and economic development, the requirements for accounting become higher. People from all walks of life require financial accounting technology. All kinds of social and economic management fields urgently need financial accounting talent. Hence, financial accounting information has received much attention. In college education, financial accounting major is welcomed and favored by students. However, financial accounting is a course with strong operability, applicability, and practicality. Cultivation of students' problem solving ability becomes the priority of financial accounting course. Thus, it is urgent to reform and innovate in a financial accounting course. Ten-year Development Plan of Educational Informationization (2011-2020) issued in 2012 explicitly indicates the following [6]: "to construct intelligent teaching environment and drive integration of information technology and education." To achieve educational informationization, Smart Classroom and digital teaching based on ARS interactive teaching mode need to be combined and applied to teaching. Sustainable development of teaching needs to be promoted not just to conform to the trend of era development but also to realize teaching management and innovation and drive teaching reform. The application of ARS interactive teaching mode based on Smart Classroom in financial accounting course can improve teaching effect of financial accounting course and help improve students' learning ability, practical ability, and innovation ability. It also cultivates a student's ability to apply financial accounting knowledge and information to serve social and economic management industry and provide high-quality financial accounting talent to society. Therefore, it has theoretical and practical significance. 


\section{State of the Art}

Domestic and overseas scholars have conducted extensive studies on financial accounting teaching. Ciudadgomez et al. [7] showed the high correlation of financial accounting teaching mode and industry setting. They set up professional courses according to the demand of accounting industry and prepared teaching material and content. Germany adopted a dual system, closely combined schools and enterprises, integrated theory and practice, and focused on the techniques of financial accounting talents. Davidson et al. [8] proposed financial accounting teaching mode with emphasis on accounting qualification on different stages. They also proposed that the accounting career was closely related to technology education. Chinese scholars also studied financial accounting course teaching reform. For example, Zhang [9] indicated that financial accounting teaching mode should be oriented to work. Zang et al. [10] pointed out that the content, function, and implementation should be combined for teaching to train professional and applied financial accounting talents. Some researchers also considered that financial accounting course practice should be set according to the requirements of accounting post to cultivate students' vocational ability [11]. With the development of information technology, information-based teaching affects financial accounting course. Both China and foreign countries have started information-based teaching reform. Research indicates that traditional teaching method lacks creativity and can neither effectively convey knowledge nor train students' comprehensive financial accounting ability. Domestic and overseas researchers showed that the development of information technology provides plenty of effective tools for financial accounting education. These multimedia tools not just help teachers design teaching courseware simply and efficiently and improve teaching efficiency but are also supported and welcomed by students. Students are highly satisfied with innovative multimedia teaching of financial accounting course. It enhances the communication between teachers and students and improves students' academic performance. The combination of digital multimedia technology and teaching information system is an important method for financial accounting course teaching innovation. Although some colleges in China have popularized multimedia teaching and digital teaching, information-based teaching means are used rarely, and the function of digital teaching is not fully exerted. Meanwhile, the information-based teaching mode is too old and fails to keep up with the development of information technology. Reforming traditional multimedia teaching is urgently needed in financial accounting course. Cooper et al. [12] proposed a classifier ranking method based on affective models; the method carefully collects training and testing sets. Each set forms a separate population and ends with a non-parametric ranking of the trained classifiers on the testing set. Results show that Smart Classroom improves a teacher's teaching effect. Agustianto [13] proposed the combination of learning path (LP) form with Adaptive learning (AL) system and applied it to the teaching system of Smart Classroom. LP serves as the foundation for teachers to construct learning process. Metacognitive awareness index (MAI) was used in this study to carry out metacognitive recognition for students to gain LP. Data show that the teaching method is accepted by teachers and students and contributes to improving teacher's lesson preparation efficiency. 
As social and economic development improves, the requirements for accounting become increasingly high. People from all walks of life require financial accounting technology. All kinds of social and economic management fields urgently need financial accounting talents. However, financial accounting is a course with strong operability, applicability and practicality. Cultivating students' problem solving ability becomes the priority of financial accounting course. Thus, it is urgent to reform and innovate in a financial accounting course. However, accounting teaching still has some defects, including the single and traditional teaching method. The teacher is the subject. At present, most colleges still adopt traditional "cramming education" method [14]. Moreover, teaching means are diversified, but the teaching effect is poor. Although information-based teaching means are increasing, most teachers only apply PPT to present course content. Students' learning initiative fails to be effectively motivated. They still passively receive knowledge and do not participate in active learning. Simple and one-sided teaching content is one of the defects of accounting teaching. The knowledge learned by students is simply repeated. The knowledge is simple, one-sided, and lacks connection. This adversely affects knowledge construction from multiple aspects and completion of effective knowledge transfer. These problems exist in financial accounting course teaching of applied colleges and are the main reasons for poor learning initiative and lack of the ability to flexibly apply knowledge.

Smart Classroom was innovatively introduced in financial accounting course teaching. ARS system was applied to improve the use efficiency of multimedia in digital teaching, optimize the process of sending information from classroom and receiving information by students, and promote interactive teaching. In addition, the multimedia circuit system with the PPT function of next page preview was introduced. The system has the PPT function of the next page preview. For example, when the teacher teaches the PPT content on the current page, he/she can view the content on the next page to help him/her connect the context, thereby preventing him/her to forget the previous content. The system also helps avoid disconnection, reduces the feeling of tension, enhances self-confidence, and averts classroom teaching accidents. This study is expected to provide reference for information-based teaching and optimization of accounting course.

\section{ARS Interactive Teaching Mode for Financial Accounting course based on Smart Classroom}

\section{1 "SMART" conceptual model of Smart Classroom}

"Smartness" of Smart Classroom involves optimal presentation of teaching content, convenient acquisition of learning resources, deep interaction of classroom teaching, context awareness and test, classroom layout, and electric management. They can be summarized into five dimensions, as follows: Showing, Manageable, Accessible, Real-time Interactive and Testing ("SMART"). The five dimensions embody the features of Smart Classroom, called "SMART" conceptual model. 
Showing: Showing mainly characterizes teaching information presentation capacity of Smart Classroom. The content should be clear. The content presentation mode should be suitable for the cognition feature of learners to enhance their understanding and processing of learning materials. Showing mainly includes two aspects, namely, visual and auditory presentation.

Manageable: Manageable mainly characterizes layout diversity and management convenience of Smart Classroom. All equipment, system, and resources of Smart Classroom should have strong manageability, including classroom layout management, equipment management, physical environment management, electric safety management, and network management.

Accessible: Accessible mainly characterizes resource access capacity and equipment access convenience in Smart Classroom. It involves resource selection, content distribution, and access speed. Rich network learning resources contribute to students' autonomous learning, interactive cooperative learning, individualized learning, and education socialization.

Real-time Interactive: Real-time Interactive mainly characterizes the ability of Smart Classroom to support teaching interaction and man-machine interaction. It involves convenient operation, smooth interaction, and interactive tracking. Convenient operation leads to natural interaction. Smooth interaction can meet the interaction demand of multiple terminals and a large data size. Interactive tracking can offer support for teacher's decision and students' self-evaluation.

Testing: Testing mainly characterizes the perception capacity of Smart Classroom to physical and learning environments. Air, temperature, light, sound, color, and smell are physical environmental factors. These factors directly influence physical and psychological activities of teachers and students.

\subsection{Environmental composition of Smart Classroom}

Smart Classroom mainly includes the subjects of education activity, system environment factors, and conditions of education activity. Through information technology means and multimedia equipment, including internet, Internet of Things, cloud computing, and data mining, the perception of network, physics, and society are integrated. The subjects of education activity include teacher, learner and administrator. System environment factors mainly include teaching, light, temperature, humidity, attendance, monitoring, and other systems. The conditions of education activity include online and offline learning resources, cloud platform supported by internet and big data, and intelligent terminal serving for teaching activity (Fig.1). 


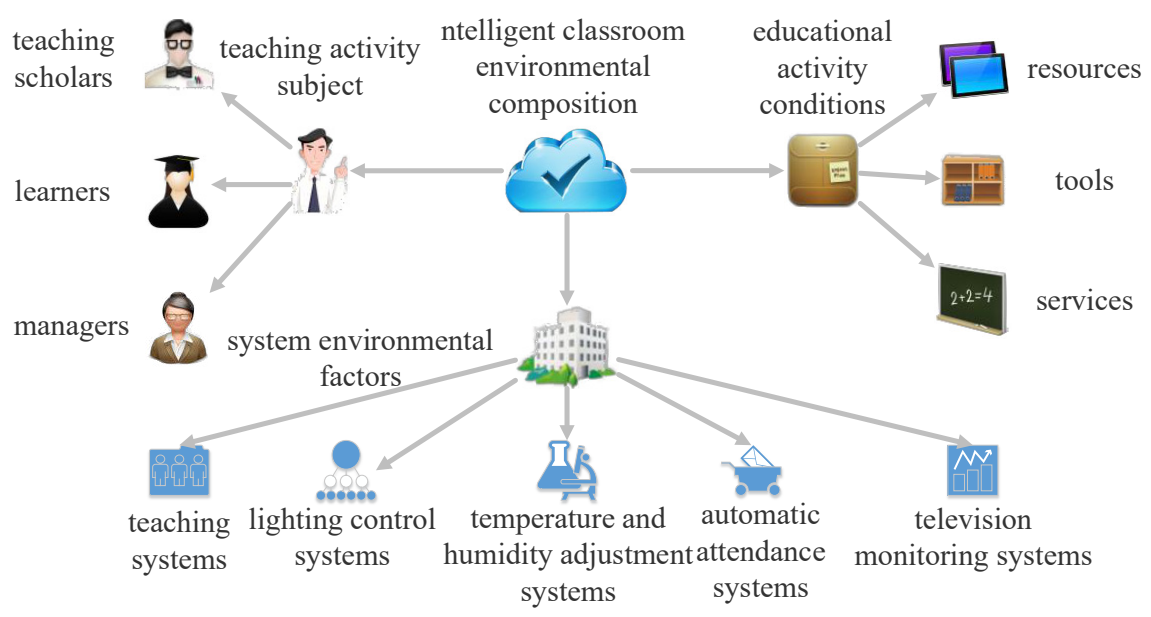

Fig. 1. Environmental composition of Smart Classroom

\subsection{Frame of ARS Interactive Teaching Mode based on Smart Classroom}

The frame of Smart Classroom teaching mode includes the following teaching process: firstly, cloud storage and smart push. Smart Classroom analyzes and stores students' learning demand through data mining and pushes relevant resources according to students' learning progress. Secondly, the teacher poses questions and creates situations through the previous demand analysis, as well as provides learning tasks and learning scenes for students. Thirdly, Smart Classroom creates personal learning space and offers personal learning mode, including self-help, exploration type, and maker type. Fourthly, Smart Classroom can carry out smart grouping for students according to the analysis of students' learning features and help students cooperate, exchange, and evaluate one another. Fifthly, for feedback evaluation, Smart Classroom can reflect students' learning information to teachers in time and help teachers diagnose and evaluate students' learning conditions. Sixthly, for after-class expansion, Smart Classroom can summarize students' learning conditions, push expansion resources, and help students study after-class expansion (Fig.2). 


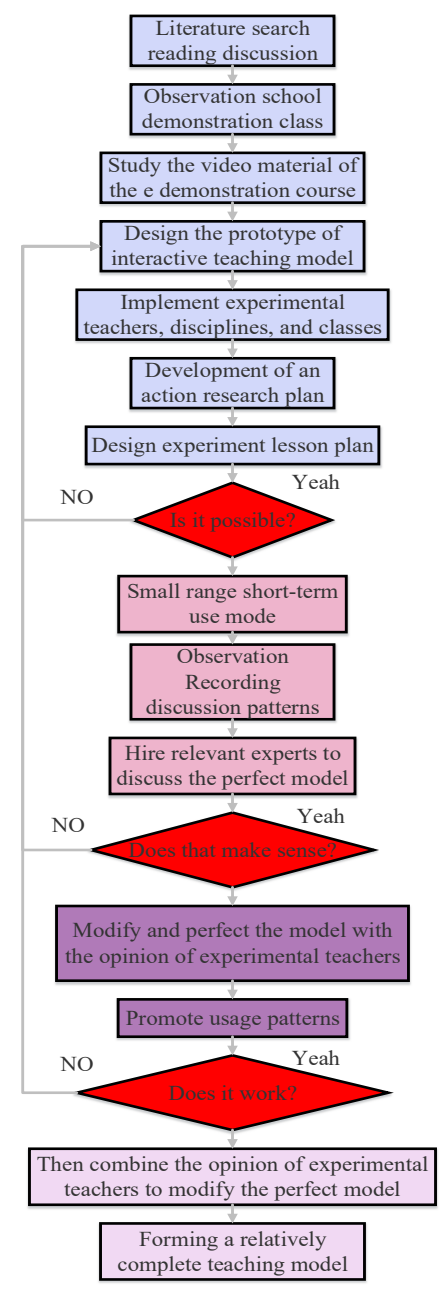

Fig. 2. Frame of teaching mode based on Smart Classroom

\section{Teaching Example and Effect}

\subsection{Teaching example}

Financial accounting course is used as the example in this study to construct ARS interactive teaching mode based on Smart Classroom for financial accounting course, during which multiple construction approaches were adopted, mainly including theory deduction method and induction method. The qualitative method was used for modeling. Meanwhile, document research, classroom observation, case analysis, and investigation were combined. The teaching mode construction is shown in Fig.3. Experiment teaching of Smart Classroom for financial accounting course is shown in Fig.4. 


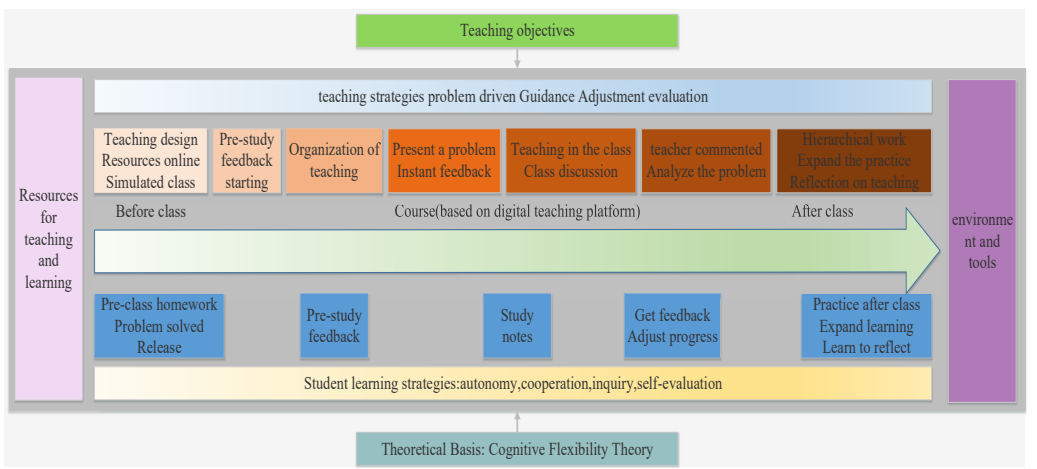

Fig. 3. Construction process of ARS interactive teaching mode based on Smart Classroom

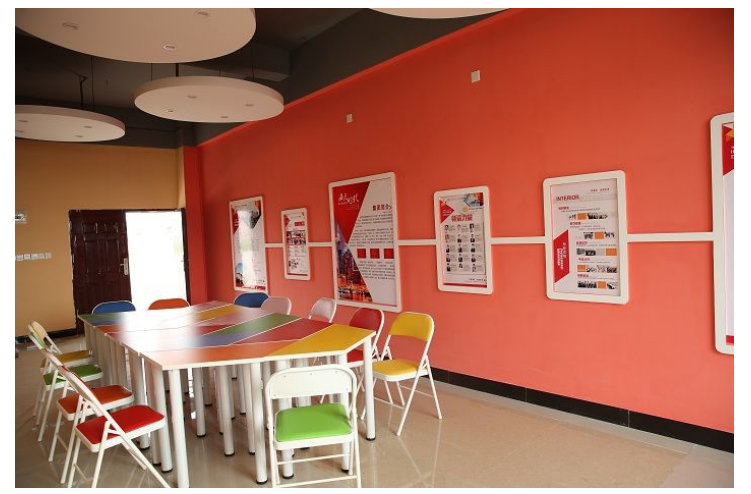

Fig. 4. Experiment teaching of Smart Classroom for financial accounting course based on ARS interactive teaching mode

Pre-class, in-class, and after-class integrated teaching: Different from traditional teaching mode, ARS interactive teaching mode based on Smart Classroom closely combines teaching interaction and practice and focuses on pre-class, in-class, and after-class integrated teaching. Based on Smart Classroom, it mainly highlights the timely feedback and the dynamic regulation functions of the ARS system. In the teaching process, the teacher is the guide, the students are the subjects, and they both interact. By combining the environment and teaching mode frame of Smart Classroom, as well as the construction process of ARS interactive teaching mode based on Smart Classroom, the financial accounting teaching mode based on ARS interactive teaching mode and Smart Classroom is constructed. The teaching mode mainly includes five aspects, as follows: teaching objective, theoretical basis, operation sequence, implementation condition, and effect evaluation. The whole mode is based on cognitive flexibility theory. The teacher mainly asks questions, guides, adjusts, and evaluates. The students mainly conduct independent study, collaborative learning, inquiry learning, and self-assessment. Thus, before class, the teacher is required to prepare for lessons, and students are required to preview. During class, the teacher should combine preview result for teaching, proposing questions, organizing discus- 
sion, and conducting commentary and explanation. Students should take notes, answer questions, interact, and improve learning. After class, the teacher should assign homework and exercises for the students to complete (Fig.5).

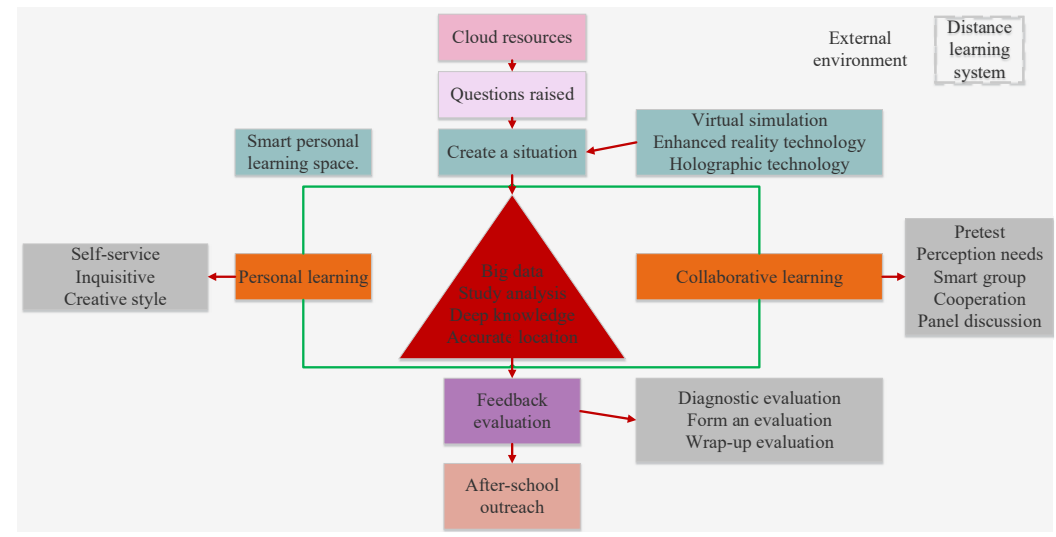

Fig. 5. Pre-class, in-class and after-class integrated teaching mode of ARS interactive teaching based on Smart Classroom

Pre-class, in-class and after-class feedback teaching: A big feature of ARS interactive teaching based on Smart Classroom is timely feedback. Thus, its teaching feedback structure mode is very important. Pre-class and after-class feedback modes are generally the homework and exercise offered by the teacher. In-class feedback mode generally involves answering questions, including review and inspection of previously acquired knowledge, understanding of new knowledge, knowledge mastery degree, and rule discovery. In class, 3-4 times of feedback should be organized. The teacher should adjust the next teaching content and questions to be proposed in time. The mode of ARS interactive feedback teaching structure is shown in Fig.6.

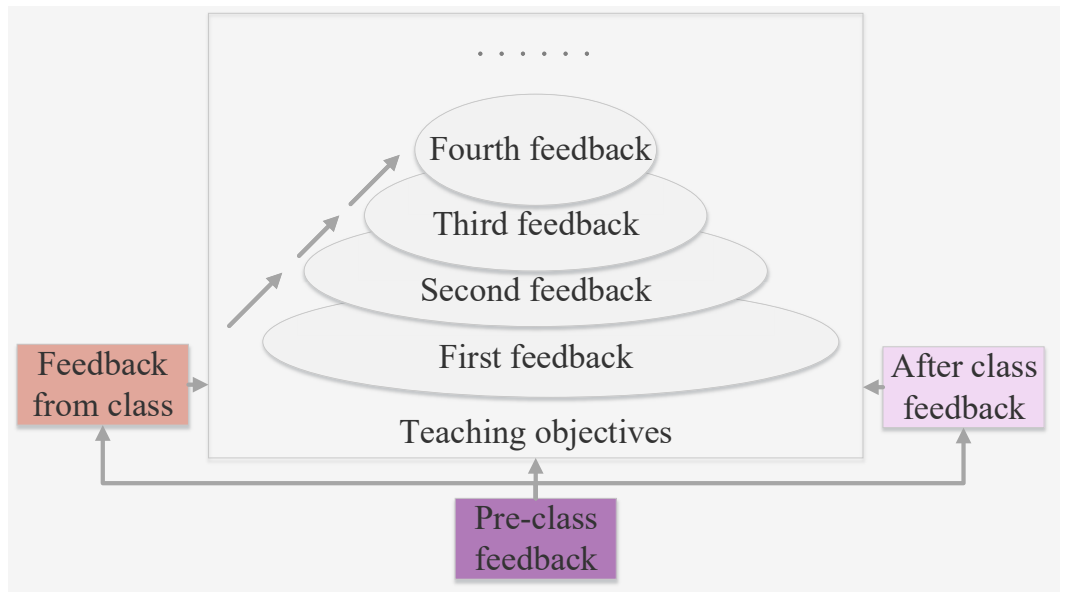

Fig. 6. Pre-class, in-class and after-class feedback teaching structure mode based on ARS 
Peer teaching: ARS interactive teaching mode based on Smart Classroom is generally crenelated with peer teaching. After the problem is known via feedback, interaction and discussion among students are required, i.e. peer interaction. Each member in the learning group first states his/her opinions and positioned learning objective. Then, data integration is conducted to include the views of all members to deeply analyze and automatically form the learning objective closest to the view of most members. Finally, the members negotiate and confirm the clarified learning objective. Next, each learner fulfill demand perception and data mining, as well as the unified learning task and learning plan formed through combining intra-group discussion. In this study, the learning process automatically recorded in the teaching process is monitored and adjusted in time. Unlike a traditional classroom, Smart Classroom focuses on utilizing maximum ability of each member and divides work according to their learning ability, learning style, personality characteristics, and learning demand. The members can conduct online communication and learn with teachers and other learners through instant mind mapping and other tools for problem solving. The teacher presents their questions through ARS Smart Classroom and discusses them synchronously with the students. Students interact with the teacher in real time via QQ and WeChat to gain the most effective learning suggestions. Finally, each group shares learning achievements and evaluate each other. Each learner can participate for selfassessment, peer evaluation, and collective assessment. The teacher summarizes and offers feedback. At last, the quantitative result would be given according to learners' learning conditions in this study. Fig.7 shows peer teaching situation of Smart Classroom based on ARS interactive teaching mode.

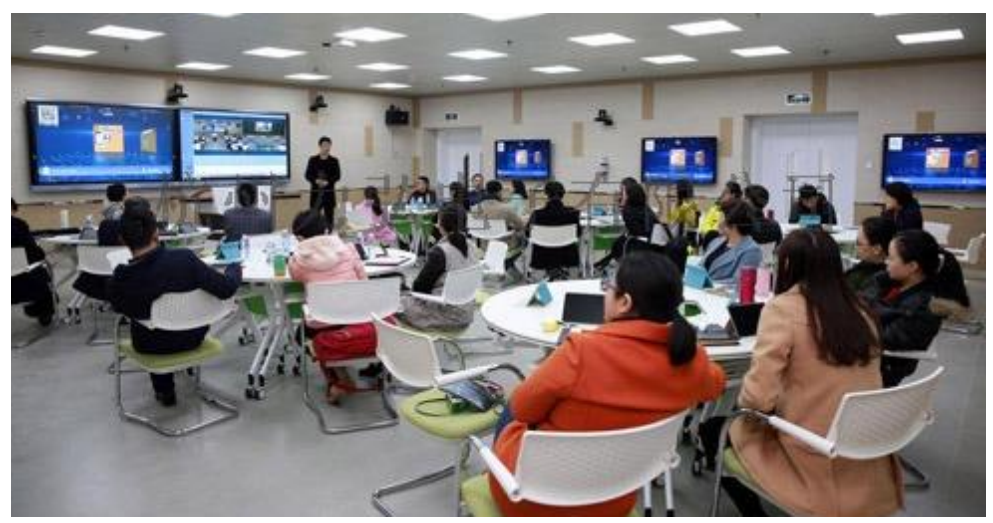

Fig. 7. Peer teaching situation of Smart Classroom based on ARS interactive teaching mode

Thus, the specific operation of this process also contributes to the organization and management of classroom teaching process. The result of feedback on question answering will influence the next teaching operation. If the rate of correct answers is higher than $80 \%$, the teacher can directly conduct commentary and analysis. If the rate of correct answers is lower than $30 \%$, the teacher needs to re-explain the key and difficult knowledge. If the rate of correct answers is intermediate, group discussion or class discussion may be carried out. Peer teaching algorithm is shown in Fig.8. 


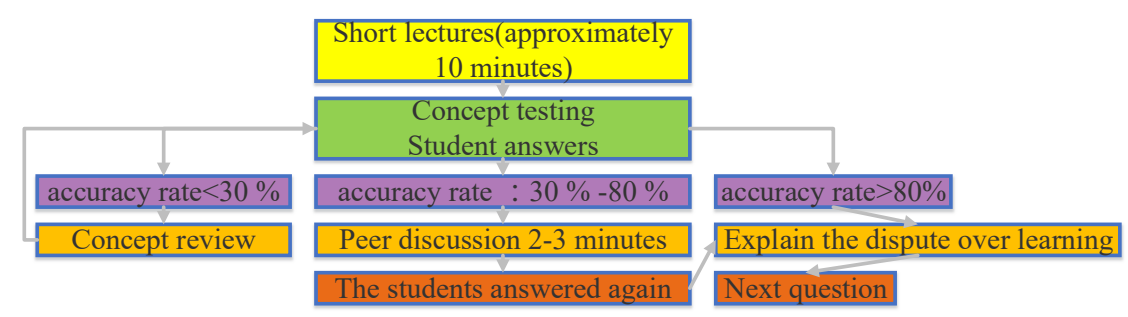

Fig. 8. Peer teaching algorithm

\subsection{Teaching effect}

The ARS interactive mode based on Smart Classroom is applied in financial accounting course teaching. The course is implemented under the environment of Smart Classroom. The teacher fully applies multimedia equipment in teaching and uses the multimedia circuit system with the PPT function of next page preview to play PPT. Students learn relevant theoretical knowledge and conduct practical operation. They provide reasons by combining cases. The teaching experiment of financial accounting course, which lasts for one semester, is implemented. Two classes are chosen as the experimental and control classes. The ARS interactive teaching mode based on Smart Classroom is applied for the experimental class, whereas the traditional teaching mode is used for the control class. The teaching duration is from March 2017 to July 2017 (36 periods). At the end of the experiment, a questionnaire survey is conducted for both classes, and the students are evaluated in terms of four aspects, namely, independent study, collaborative communication, classroom activity, and innovative thinking. The differences of both classes are analyzed, and the teaching effect of ARS interactive teaching mode based on Smart Classroom is explored. The results are shown in Table 1.

Table 1. Questionnaire survey results of both classes

\begin{tabular}{|l|c|c|c|c|c|c|}
\hline \multirow{2}{*}{\multicolumn{1}{|c|}{ Evaluation }} & \multicolumn{3}{c|}{ Experimental class } & \multicolumn{3}{c|}{ Control class } \\
\cline { 2 - 8 } & Good & Moderate & Not good & Good & Moderate & Not good \\
\hline Autonomous Learning & 80.2 & 12.3 & 7.5 & 47.8 & 37.8 & 14.4 \\
\hline Cooperative communication & 83.4 & 11.7 & 4.9 & 28.6 & 55.7 & 15.7 \\
\hline Classroom activities & 75.4 & 13.3 & 11.3 & 19.6 & 60.5 & 19.9 \\
\hline Innovative thinking & 33.5 & 55.4 & 11.1 & 7.9 & 65.7 & 26.4 \\
\hline
\end{tabular}

Table 1 shows that the experimental class showed the significant differences with control class in independent study, collaborative communication, classroom activity and innovative thinking. Except for innovative thinking, most students in the experimental class are very satisfied with independent study, collaborative communication, and classroom activity. For innovative thinking, although the result is not very satis- 
factory, the classes differed. From the survey results, ARS interactive teaching mode based on Smart Classroom has significant positive effect on financial accounting course teaching and can obviously improve the teaching effect. The classroom observation also reflects this situation. Obviously, the students in experimental class listen to the teacher carefully and have stronger learning interest. They show higher classroom participation and provided a higher rate of correct answers to questions.

\section{Conclusion}

The construction of ARS interactive teaching mode based on Smart Classroom can reform the traditional financial accounting teaching mode, solve the problems that cannot be solved in traditional teaching mode, and achieve what traditional teaching cannot achieve. It is an application of information-based teaching. It can achieve timely and deep interaction in financial accounting course, promote the improvement of students' dominant position, help teachers teach according to students' learning features, improve work efficiency and learning effect, and provide real and vivid scene simulation. It is the new direction of digital teaching. Although this study has verified the significant positive effect of ARS interactive teaching mode based on Smart Classroom on financial accounting course, the mode of development is still not developed. Thus, when this mode is applied to teaching, the teacher must pay attention to the following problems. The teachers should be familiar with the relevant hardware and software of Smart Classroom to avoid teaching accidents caused by misoperation and their corresponding impact on teaching effect. The administrators must maintain relevant equipment and software and avoid the scenario in which the course cannot be implemented due to the inability to use the equipment. The teachers must pay attention to subject differences while applying the mode, attach importance to subject differences, and subtly adjust the mode so as to adapt to subject features. Meanwhile, teachers should realize the limitation of this mode. Any teaching mode can be changed. ARS interactive teaching mode based on Smart Classroom cannot be applied mechanically. It is to be used as the main frame. Meanwhile, the influence of other teaching factors are considered to design and adjust the teaching process.

In general, teaching effect of financial accounting course can be significantly promoted by constructing pre-class, in-class, and after-class integrated ARS interactive teaching mode based on Smart Classroom environment and Smart Classroom teaching mode frame and supported by multimedia circuit system with PPT function of next gape preview, forming pre-class, in-class and after-class teaching feedback structure mode, and combining peer teaching. It is necessary to study and explore this mode and expand it to teaching and practice in other courses to construct more rational ARS interactive teaching mode based on Smart Classroom and to facilitate informationbased teaching reform. 


\section{References}

[1] Ferreira, M.J.M. Intelligent classrooms and smart software: Teaching and learning in today's university. Education \& Information Technologies, 2012, vol. 17(1), pp. 3-25. https://doi.org/10.1007/s10639-010-9134-8

[2] Kay, R.H., Lesage, A. Examining the benefits and challenges of using audience response systems: A review of the literature. Computers \& Education, 2009, vol. 53(3), pp. 819-827. https://doi.org/10.1016/j.compedu.2009.05.001

[3] De Juan, N.O., \& Laborda, J.G. Digital games in language learning and teaching. Educational Technology \& Society, 2013, vol. 16(4), pp. 290-293.

[4] Gao Y.L. Cognition and Discussion on the Digital Teaching of Diagnostics Based on Traditional Chinese Medicine. China Continuing Medical Education, 2017, vol. 9(3), pp. 1518.

[5] Yao Y., Wu, X.N., Deng, M.F. Application of digital photomicrography technology in practice teaching of natural medicine. Zhejiang Medical Education, 2013, vol. 23(1), pp. 16-17.

[6] 王键. 以教育信息化推动职业教育改革创新——解读《教育信息化十年发展规划 (2011-2020年)》[J]. 中国教育信息化, 2012(11):4-7.

[7] Ciudadgomez A. Design of the Accounting Course Focusing on the Development of Competences.[J]. Journal of Research in International Education, 2011, 7(5):15-22.

[8] Davidson L H, Francisco W H. Changes to the Intermediate Accounting Course Sequence.[J]. American Journal of Business Education, 2011, 2(7):55. https://doi.org/10. 19030/ajbe.v2i7.4584

[9] 张莉. 以职业能力为导向的高职财务会计课程改革初探 [J]. 财会学习, 2016(3):162162. (将原文中的“上官健”换成“张莉”)

[10] 蔵泽华. 基于应用型人才培养的会计学专业“三位一体”实践教学体系构建 $[\mathrm{J}]$. 经营管 理者, 2016(12).(将原文中的“沈应仙”换成“㶓泽华”)

[11] Liu Y. Construction and Comprehensive Evaluation of Accounting Professional Competence Framework of Higher Vocational School Students_-Taking Structural Equation Modeling and AMOS Software as the Analytical Tool[J]. Vocational \& Technical Education, 2012.

[12] Cooper D G, Muldner K, Arroyo I, et al. Ranking feature sets for emotion models used in classroom based intelligent tutoring systems[C]// International Conference on User Modeling, Adaptation, and Personalization. Springer-Verlag, 2010:135-146.

[13] Agustianto K, Permanasari A E, Kusumawardani S S, et al. Design adaptive learning system using metacognitive strategy path for learning in classroom and intelligent tutoring systems[J]. 2016, 1755(1):070012.

[14] Hervás-Gómez C, Morales P T. Real and ideal perception of the intelligent classroom environment of future teachers[J]. 2018, 1(1):86-106.

\section{$7 \quad$ Author}

Lingling Zhang is a lecturer in the University of Science and Technology Liaoning, Anshan, China (15040760968@163.com).

Article submitted 7 October 2018. Resubmitted 12 November 2018. Final acceptance 15 November 2018. Final version published as submitted by the author. 